\title{
State as a stakeholder in the development of metallurgical industry corporations
}

\author{
Olena Kozyrieva ${ }^{1 *}$, Nataliia Orlova ${ }^{2}$, Maksym Zabashtanskyi ${ }^{3}$, Andrii Rogovyi ${ }^{4}$, and Danylo \\ Berezovskyi ${ }^{5}$ \\ ${ }^{1}$ National University of Pharmacy, Doctor of Economics, Professor, Head of the Department of \\ Management and Public Administration, 61057, 53 Pyshkinskaya street, Kharkiv, Ukraine \\ ${ }^{2}$ Simon Kuznets Kharkiv National University of Economics, Dr. Sc. (Public Administration), Professor \\ of Public administration and regional economics, Kharkiv, Ukraine \\ ${ }^{3}$ Chernihiv Polytechnic National University, Doctor of Economics, Professor, Director Educational- \\ Scientific Institute of Business, Environment Management and Tourism, 14035, Chernihiv, Shevchenko \\ str.,95, Ukraine \\ ${ }^{4}$ Chernihiv Polytechnic National University, Doctor of Economics, Professor, Department of tourism, \\ 14035, Chernihiv, Shevchenko str.,95, Ukraine \\ 5 «International Scientific and Technical University», PhD of Public Administration, Department of \\ Management and Public Administration, (ISTU) Kyiv, Ukraine
}

\begin{abstract}
The article substantiates the expediency of studying the role of stakeholders in the formation and implementation of corporate social strategy within the activities of corporations in the metallurgical industry in the Ukraine. The important role of the state, as a stakeholder, in establishing effective relations with corporations in the implementation of Ukraine's sustainable development strategy has been proved. The purpose of the article is to determine the capabilities of the state and its impact on the implementation and development of corporate social responsibility strategy in corporations of the metallurgical industry of the Ukraine. The information is based on the reports of Metinvest Corporation, DTEK and the CSR Development Center. The article identifies state economic and marketing incentives for the development of socially responsible behavior of corporations in the metallurgical industry. The analysis of the directions of the corporate social responsibility strategy of Metinvest and DTEK is carried out, and the comparative characteristic of the ways of ecological responsibility of corporations is conducted. The regional features of the formation of the strategy of social responsibility for multinational corporations are determined. The conclusions indicate that the level of interaction of metallurgical corporations with stakeholders is still at a low level, but areas (projects) of corporate social responsibility for the implementation of state national programs have already been formed.
\end{abstract}

\footnotetext{
*Corresponding author: yakakos74@gmail.com
} 


\section{Introduction}

The implementation of the 2030 Sustainable Development Strategy stipulates that the state becomes the main stakeholder and partner in promoting the ideas of corporate social responsibility. The economic crisis in the state has affected the government's activity in creating conditions for the introduction of corporate social responsibility (CSR) within corporations in the metallurgical industry. The COVID-19 pandemic also outlined social and environmental problems, especially in the regions of Ukraine where there are powerful industrial enterprises. In their national CSR policies, public authorities pay special attention to the competitiveness of industries on the world market and the impact of these industries on the further development of society. Therefore, it is important to define the role of the state as a stakeholder in the development of mechanisms to ensure the implementation of the concept of social responsibility for enterprises in the metallurgical industry.

The research of Kraplych R. [1], Smith M. [2], Chernikov G. [3], Holme R. [4] is devoted to the general theoretical issues of introduction of corporate social responsibility within the corporations. Burmaka T. [5], Kharlamova A. [6], Lahunova I. [5], Melnykovych O. [5], Medvedchuk O. [] 5], Nepomnyashchyy O. [5], Orlova N. [5-7] and the Center for CSR Development [8] conducted analyzes of the applying the principles of corporate social responsibility in the activities of corporations and trends in the formation of the company's reputation at the international level.

The purpose of the article is to survey the capabilities of the state and its impact on the implementation and development of corporate social responsibility strategy in corporations of the metallurgical industry of Ukraine.

\section{Results and Discussion}

The development of corporate social responsibility is considered in accordance with the development of the internal and external environment of the corporation. External and internal environment of corporate responsibility is an area of interaction and relationships within the company, with partners, society - all stakeholders in the company's activities in the implementation of its social programs aimed at achieving benefits for the company and society in whole [6].

The main factors influencing the implementation of the concept of CSR in the country are the structure of the economy, foreign investment, inefficient social protection system, heavy regulatory burden, weak local societies, lack of institutional support, labor legislation.

The activities of corporations are evaluated primarily by the quality of their products and services, as well as their relationship to employees and suppliers. The contribution of companies to the national economy, environmental protection, fairness and participation in charity are important, but secondary factors.

In the internal environment, the focus is made on such aspects as human resource management, workplace safety management, adaptation to change, environmental and natural resource management.

The concept of "stakeholders" assumes that the organization has certain groups of stakeholders (shareholders, employees, customers, suppliers, the state, etc.) who influence the organization or who are influenced by the organization itself, and who can be considered as those who put on organization particular responsibilities [5].

The role of the state is to develop a strategy, regulatory framework and environment in which CSR will prosper and contribute to national development. First of all, the state is the main locomotive and controller of the implementation of responsible approaches to doing business. 
Economic government instruments for creating appropriate conditions for the implementation of CSR strategy in corporations can be the following: subsidies for the purchase of CSR consulting, implementation of standards, grants, low interest rates on loans for CSR projects, development funds), economic measures for the implementation of CSR practices) (introduction of licenses, taxes, tax benefits, special taxes), definition of qualitative and quantitative goals for monitoring the implementation of CSR strategy.

Government marketing tools for the implementation of CSR strategies may be state awards for voluntary improvement of CSR processes and management systems (encouragement of voluntary improvement of environmental standards of production or social responsibility of the company, by means of a distinctive mark (label) on the product or company statement; voluntary external audit by state bodies, promotion of standardization).

It is the state, as the main stakeholder for corporations in the metallurgical industry, that creates the conditions for the effective development and implementation of a socially responsible strategy. The main factors influencing the implementation of the CSR concept are: state regulation of CSR, institutional support, state social policy, international standards in this area, the level of foreign investment, the structure of the economy.

When building a CSR strategy, special attention should be paid to the interaction of corporations with non-profit organizations, since, firstly, they represent public initiatives, and secondly, they should help companies and the state in implementing a number of social projects, because they can do it more professionally and efficiently from economic point of view. By implementing its own programs or in partnership with local authorities and non-profit organizations, the corporation receives a number of benefits.

Let's consider the mechanisms for implementing the CSR concept in the largest metallurgical industry, Metinvest Corporation, in comparison with DTEK, the leader in Ukraine's fuel and energy sector. Two industrial corporations are part of SCM's most powerful holding company in Ukraine.

Metinvest is the largest vertically integrated mining and metallurgical company in Ukraine and one of the leading players in the global metallurgical industry, whose products are represented in more than 75 countries. Metinvest's main shareholders are SCM Group (75\%) and Smart Holding (25\%). Metinvest consists of 16 enterprises in the coke, coal, mining and metallurgical industries, seven trading companies and three transport companies located in Ukraine, Europe and the United States. In Europe, Metinvest is represented by two metallurgical plants in Italy - Ferriera Valsider and Trametal. Metinvest also includes the British steel plant Spartan UK and one of the leading coking coal producers in the United States, the United Coal Company [9].

DTEK is a leader in Ukraine's fuel and energy sector. DTEK includes prominent coal producers and leading Ukrainian energy companies. DTEK is also one of the largest companies in the electricity market. The main consumers of electricity are large industrial enterprises of Ukraine (almost $98 \%$ of consumption).

At Metinvest and DTEK, special structural units deal with environmental issues. At Metinvest, the Environmental Protection Department was established in 2008 as part of the Directorate for Industrial Safety and Ecology. From the very beginning, the directorate employed 16 people, 13 of whom were directly involved in labor protection and industrial safety. The Directorate also works with Metinvest executives at all levels to raise their awareness of health and safety issues. At DTEK, the Department of Safety and Environmental Protection has been operating since 2007 and was transformed into a directorate in 2010. The task of such directorates is to develop and implement a modern integrated environmental management system. Environmental services operate at all Metinvest and DTEK enterprises. They constantly monitor the state of sources of action on atmospheric air, soils, groundwater. Metinvest and DTEK industrial holdings aim to minimize the impact of production processes 
on the environment. To achieve this goal, appropriate action programs are developed, which are included in the CSR strategy of these corporations (Table 1).

As a result of the activities of industrial enterprises, pollutants and greenhouse gases are released into the atmosphere, wastewater and waste are generated, and land is disturbed. According to these aspects of influence the basic directions of nature protection activity of the enterprises are formed: protection of atmospheric air, including reduction of level of emissions of greenhouse gases; protection of water bodies; rational use of land resources and waste management; energy saving.

Table 1. The main activities in the field of environmental protection

\begin{tabular}{|c|c|}
\hline Metinvest & DTEK \\
\hline $\begin{array}{l}\text { Tracking and managing possible } \\
\text { environmental risks } \\
\text { Emphasis on measures to warn of the negative } \\
\text { impact of industrial cycles on the } \\
\text { environment } \\
\text { Rational use of natural, raw materials and } \\
\text { energy resources } \\
\text { Implementation of high-quality environmental } \\
\text { monitoring of current operating activities and } \\
\text { environmental impact assessment of planned } \\
\text { investment activities }\end{array}$ & $\begin{array}{l}\text { Introduction of a unified environmental } \\
\text { management system } \\
\text { Implementation of the program to meet the } \\
\text { requirements of the EU Directive "On } \\
\text { limiting emissions of certain pollutants from } \\
\text { large combustion plants" } \\
\text { Implementation of environmental measures at } \\
\text { coal and generating enterprises } \\
\text { Implementation of projects to reduce } \\
\text { greenhouse gas emissions into the atmosphere } \\
\text { under the Kyoto Protocol } \\
\text { Rational use of energy resources }\end{array}$ \\
\hline
\end{tabular}

Corporate social responsibility is a philosophy of behavior and a concept of building the main and additional activities of the business community, companies and individual managers, according to which managers:

conduct the main business as honestly and efficiently as possible, producing quality products and providing quality services to consumers, developing harmonious relationships with suppliers and business partners;

consciously and voluntarily make investments (financial and non-financial investments) in the development of society as a whole in the social, economic and environmental spheres, which are directly related to the main activities of the company and go beyond the statutory minimum;

voluntarily carry out partnership programs and projects for the development of the community on the territory of which their enterprises are located; consistently and systematically implement investment programs in the development of the company's human resources and human potential; care about increasing the welfare of their shareholders [2].

Ukrainian corporations implement a significant number of initiatives and projects on corporate social responsibility, which make a significant contribution to the implementation of the Sustainable Development Goals [10]. Among the most common practices - educational activities for the formation of soft skills, programming skills; transfer to medical institutions of equipment, medicines for treatment of sick children; internship and youth employment programs, etc. The vast majority of practices are aimed at children and young people, quite a significant part - at employees. Accordingly, Objective 4 "Quality Education", Objective 8 "Decent Work and Economic Growth" and Objective 3 "Good Health and Prosperity" became priorities for Ukrainian business. The analysis of the compliance of the cases of the CSR Case Competition with the national task of the Sustainable Development Goals shows that the highest level of compliance was recorded for the cases aimed at achieving Goal 4 "Quality Education" (Fig. 1) and Goal 10 "Reducing inequality" [11,12-15]. 
According to the Center for CSR Development, multinational companies in Ukraine, including the metallurgical industry, understand social responsibility mainly as a policy of staff development and support (10 out of 13 companies), investment in regional development (8 out of 13 companies), charitable assistance, protection environment and assistance to ATO soldiers and residents of the ATO zone (7, 6 and 6 companies, respectively). Companies in the East of Ukraine most often, compared to companies in other regions, include CSR investments in the development of the region, charitable assistance, anti-corruption and assistance to ATO soldiers. Companies located in the North, more often than companies in other regions, attribute to CSR participation in the development of reforms and laws and the implementation of environmental projects [12-15].

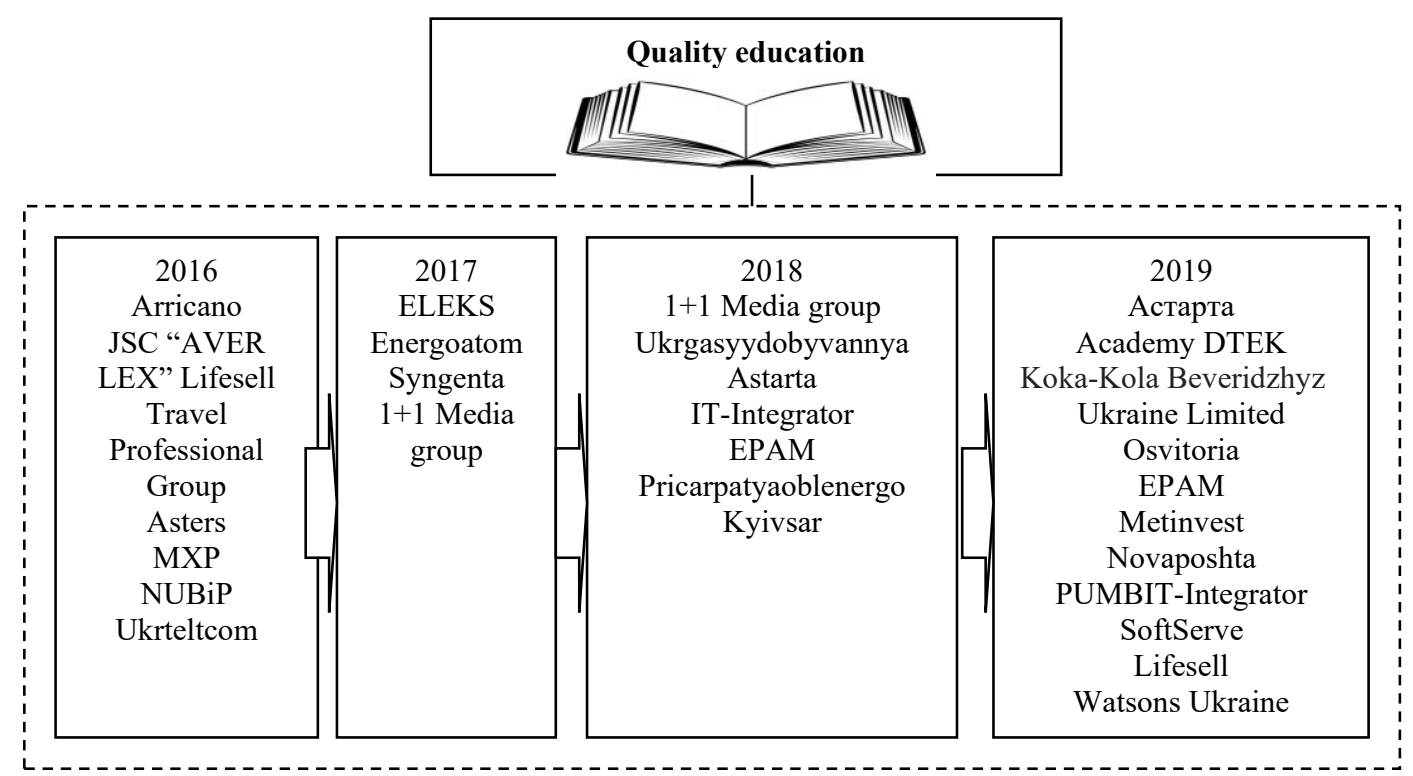

Fig. 1. Participation of corporations in the implementation of the goal of sustainable development "Quality education"

The main directions of CSR in Metinvest are presented in Fig. 2. When forming a CSR behavior strategy, the corporation must take into account the specifics of public administration in this area. Under the influence of the community, the state, the responsible behavior of the corporation to consumers, stakeholders, the reputation of the corporation is formed as a measure of evaluation of the corporation's activities in socially responsible business.

Stakeholder interests remain low enough for metallurgical corporations. Most often, companies take into account the interests of consumers and public authorities, the least - nongovernmental organizations and research organizations, educational institutions. Enterprises are engaged in the development of measures and programs on corporate social responsibility and their implementation independently, taking into account, mainly, only the interests of consumers and local authorities, which remain the main external partner. The level of cooperation with other stakeholders - public organizations, media, scientific (specialized) institutions - is also just beginning to develop. 


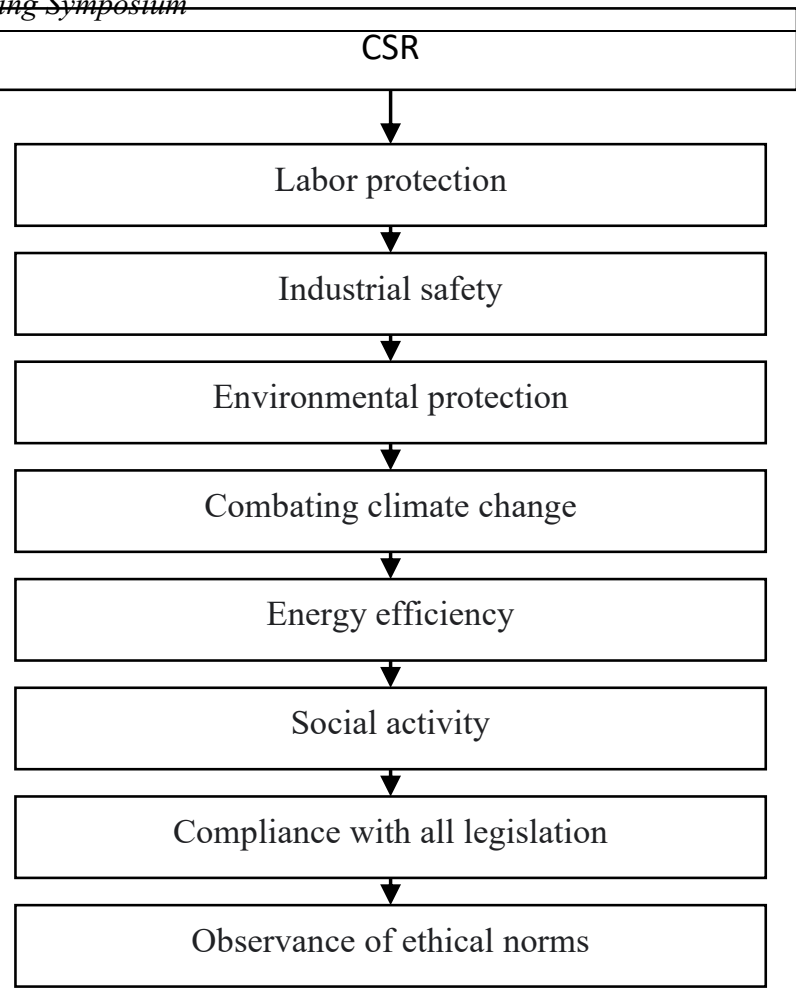

Fig. 2. The main directions of CSR in Metinvest

Source: developed by the authors

It should also be noted that the main incentives for the implementation of CSR in the activities of corporations by the state are preferential taxation, reduction of administrative pressure on local authorities and acquaintance with positive examples of implementation of programs (projects) on corporate social responsibility in the world.

\section{Conclusion}

The findings of the study show that the level of development and implementation of CSR practices in Ukraine is still low, due to the lack of interest of corporations themselves, political and economic conditions of corporate relations, inefficient corporate governance structure, uncertain priorities of corporate social responsibility, unbalanced corporate governance strategy in Ukraine. Only the largest corporations of the metallurgical industry and other sectors of the Ukrainian economy are able to participate in the implementation of sustainable development of the state and implement effective mechanisms of corporate social responsibility in Ukraine. Metinvest Corporation has based its CSR strategy on social and environmental responsibility. The state, for its part, as a stakeholder, is interested in implementing educational and environmental projects that shape a conscious democratic society.

\section{References}

1. R. Kraplych, Corporate social responsibility of the Ukrainian business: experience of the Ostrozkikh Foundation (Rivne, 2005)

2. M. Smyt. Korporatyvnaia sotsyal'naia otvetstvennost' - prosto bol'shaia byznesparadyhma [Corporate social responsibility is just a big business paradigm]. Retrieved 
from http://www.csrjournal.com/sferu-kso/2025-korporativnaja-socialnaja-otvetstvennostprosto.html (2009)

3. H. Chernykov. Sotsyal'naia otvetstvennost' ochen' bol'shykh korporatsyj [Social responsibility of very large corporations]. Retrieved from http://www.csrjournal.com/lib/analiticarticle/2044-socialnaja-otvetstvennost-ochenkrupnykh.html (2009)

4. R. Holme. Corporate social responsibility: making good business sense, january 2000. Retrieved from www.wbcsd.org/web/publications/csr2000.pdf (2011)

5. T. Burmaka,, N. Orlova,, O. Nepomnyashchyy, O Melnykovych, O. Medvedchuk, I Lahunova. Social investment as a tool of corporate social responsibility realization in Europe. 35th IBIMA International Business Information Management Conference (Spain, 2020)

6. N. Orlova, A. Kharlamova, Economic Journal-XXI, 3-4(1) (2014)

7. N. Orlova, Economic Journal-XXI, 5-6(1) (2013).

8. 10 rokiv rozvyvayemo KSV v Ukrayni. Retrieved from https://csr-ukraine.org/ (2020)

9. Stal', scho z'iednala misto. Retrieved from https://metinvestholding.com/ua (2006)

10. Pro Tsili staloho rozvytku Ukrainy na period do 2030 roku. Retrieved from https://zakon.rada.gov.ua/laws/show/722/2019\#Text (2019).

11. Vnesok ukrains'koho biznesu v realizatsiiu Ukrainoiu Tsilej staloho rozvytku 2016-2020 r.r.. Retrieved from https://csr-ukraine.org/research/vnesok-ukrainskogo-biznesu-sdg/ (2021)

12. Nasha filosofiya. Retrieved from https://csr-ukraine.org/pro-nas/ (2021)

13. Svetlana Grigashkina, Olga Garafonova and Victoriya Marhasova, E3S Web Conf., 41, 04006 (2018)

14. Y. Lazarenko, O. Garafonova, V. Marhasova, S. Grigashkina, O. Kozureva// Lazarenko Y., Marhasova, E3S Web of Conferences, 134, 03011 (2019)

15. Y. Lazarenko, O. Garafonova, S. Grigashkina and I. Verezomska, E3S Web of Conferences, 105, 04042 (2019) 